\title{
Role of Buddhism in World Peace Environment Application
}

\author{
Snehansh Sinha, Swetank Sinha and Jai Gopal Sharma
}

\begin{abstract}
Buddhism is not just a word or a religion. It is a way of living life. A living style of 350 million people around the world [1]. To overcome the miseries and horrors of life Buddha provides 8-fold path. Environment of the world presently is at a catastrophic stage. Every action has a reaction. Human actions of destruction are now having their reaction resulting into degradation of environment. Water degradation, soil degradation and this paper aims at collaboration of 8 -fold path to human actions. This paper also deals with 4 noble truth and not self-theory.
\end{abstract}

Index Terms - Buddhism, 8-fold path, Environment, 4 Noble Truth, Skandhas.

\section{INTRODUCTION}

Buddhism aims for amelioration of body and soul of people and attain Nirvana. The pains and sufferings are not on account of any chance. They are due to the causal principle of the empirical world, Every event has a cause. Human actions done in the past lay foundation to the outcome of the reactions in the future. All our actions have simple aimed at exploiting the nature for self good and this has brought mankind towards its own destruction. Man has not only caused damage to the environment, he has damaged the future of mankind and limited their life on the Earth. This has caused the need of environment awareness and environmental engineering at all levels of schooling.

\section{FOUR NOBLE TRUTH}

Buddha taught many things, but the basic concepts in Buddhism can be summed up by the Four Noble Truths [4] and the Noble Eightfold Path.:

$1^{\text {st }}$ Noble Truth- Buddha begins it with saying "Life is Dukkha" that means pains and sufferings of life exist in the world and are not illusions, they are facts and the factor of their existence is impermanence [7]. According to Buddha, everything is bound to change. The devastated stage of environment will also change and improve.

$2^{\text {nd }}$ Noble Truth- Buddha rejects chance as a cause of pains and sufferings. He argues that if pains and sufferings are on account of a chance then there wouldn't be possibility to end them as it would end when some other chance comes. He further

Snehansh Sinha and Swetank Sinha are Student, Delhi Technological University, India (e-mail: snehanshsinha98@gmail.com)

Bachelor's in Technology in Environmental Engineering from Delhi Technological University (e-mail: snehanshsinha98@ gmail.com) gives 12 causes of pains and sufferings of life known as doctrine of dependent origination or Pratityasamutpada.

$3^{\text {rd }}$ Noble Truth- When Buddha was asked to tell the nature of Nirvana, he didn't say anything and kept silent. His disciples framed 2 interpretations of his silence; positive and negative.

$4^{\text {th }}$ Noble Truth- Buddha for the attainment of Nirvana gave 8 fold path or Ashtangika marga such as right view, right action, right speech etc and a person must go through these 8 paths to attain Nirvana.

The world today is full of miseries and horrors of life like cultural misunderstanding, discrimination, segregation, racism, bigotry, conflict, hate crime, violence, war, terrorism, mass murder, ethnic cleansing, and even genocide. The world now needs a different way to live life to attain a peaceful and harmonious environment. It has become the need of the hour to prioritize things and get things straight. For example, "Humanity prevails over Religion".

\section{ENVIRONMENTAL APPLICATION}

Buddha holds that every event has a cause. The world we live also has a cause, our actions and thoughts are physical and mental event, so they must also have a cause. The world today is dying, the natural flora and fauna has been catastrophically affected by our selfish actions. Our crime to this mother nature has now reached its peak. THERE IS ENOUGH FOR THE NEED, BUT NEVER FOR THE GREED [6]. The available resources are being exploited extravagantly, causing fundamental problems like water scarcity, soil degradation. This is the reason that many colleges have introduced environmental engineering in its curriculum like Delhi Technological University. There is a uniqueness to the solution created by mixing adequate thoughts of Buddhism to Environmental issues. The environment can be very well protected by Buddha's thoughts. The need of sustainable development and awareness of environmental engineering has become the need of the hour. Those students who for once get connected to their environment are the ones who can save it. Just like the famous quote, People who are crazy enough to think of changing the world are the ones who actually do.

\section{DOCTRINE Of DEPENDENT ORIGINATION}

The main objective of this doctrine was to prove that the pains and sufferings of life are not on account of chance. If their presence is considered to be a chance then their removal will also depend on another chance and it will not be in our control to remove them. As result the whole aim and objective of attaining 
Nirvana will be defeated. Nirvana is to attain highest bliss. Buddha says that every event has a cause. Nothing is uncaused and each event has its dependence on its previous event. This is called Doctrine of Dependent Origination. So what happens in today's world is due to some action done in the past. The war and terrorism today is due to some evil actions done in the past. Still if we continue to commit those mistakes then how can we expect for a bright future. It has been rightly said, "You reap what you sow". So now we need to broaden are thoughts as suggested by Buddha. To achieve a peaceful life or Nirvana Buddha provides 8-fold path [3]-

1) Right View: The nations in the world can at least keep right view among each other. A sense of friendship might take us all a long way towards prosperity. In terms of Environment, a right view of the world as mother nature will definitely give fruitful result.

2) Right Resolve: An environment should be created that is away from cruelty and is non-ill will. This shall aid contemplation of impermanence, sufferings and non-Self.

3) Right Speech: The talks between every person or nation shall aim for salvation. Their speech should have no lie, rudeness or any pessimistic view. Though our environment has reached the lowest stage but effort with optimistic view will surely help in environment protection

4) Right Conduct: This act focuses more on "To live and let live" that means to live harmoniously and letting everyone live harmoniously. Human actions need to be aimed in accordingly where no damage is done to the nature.

5) Right Livelihood: Right Livelihood aims at attaining only the basic requirements which are sufficient for one. This idea has also laid the foundation of sustainable development. We live in a world which has limited resources and we, a small proportion of people can't just spend it extravagantly. The damage and exploitation done to nature is due this, a sense of satisfaction should be brought in our thought. A change is mindset is the need of the hour.

6) Right Effort: Avoid all such actions or acts that has negative impact or disturbance in one's meditation or environment should be completely eliminated or exponentially reduced.

7) Right Mindfulness: The mind should be $100 \%$ at work. In the world, we find lot of disharmony due to lack of effort put by the people whether it is within an organization among the employees and leader or else it is on schools where it is among students and teachers. Any field requires $100 \%$ focus. Attaining Nirvana requires full concentration along with faith.

8) Right Samadhi: This is basically practicing 4 stages of meditation culminating into unification of mind. In terms of environment, the above 7 stages should be performed with faith and an optimistic approach.

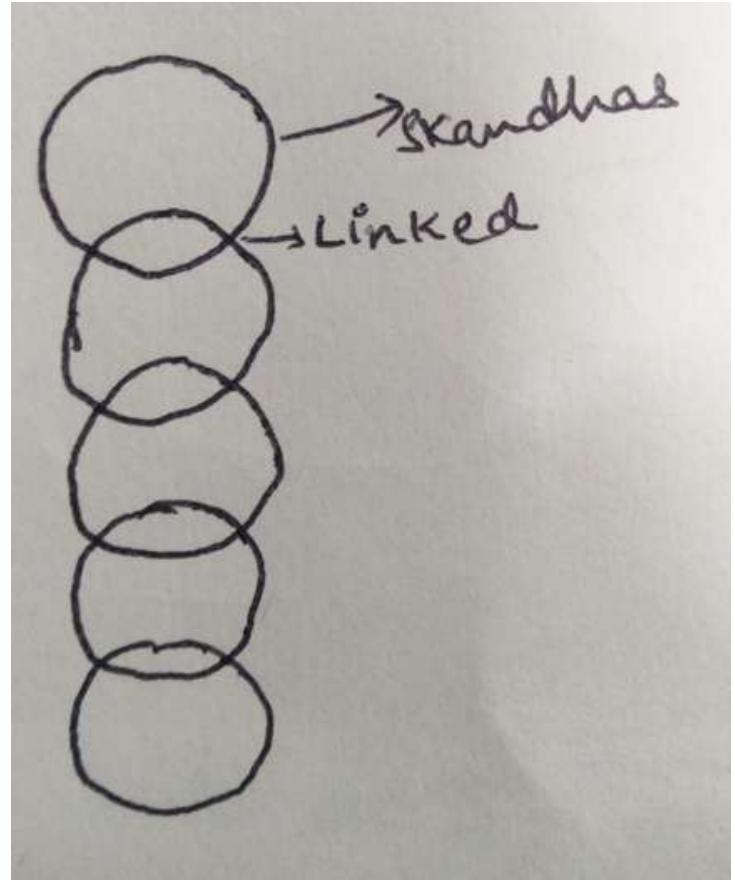

Fig. 1: Linked Skandhas

\section{NIRATMAVADA/ Not SELF THEORY}

Buddha has given a remarkable theory which aims at linking soul. This also shows that everything in the world in linked to another thing. This is a chain and disturbing 1 point in the chain can have its impact on the entire system. Today harming something or somebody has become an attitude of life which is causing discords. People don't realize that this is a chain, once you cause harm to someone or the nature you initiate this process which will go on and will sometime later cause problems for one's own self. Almost all the philosophers accept soul to be permanent and Immortal. Buddha rejects soul to be permanent and immortal. So, his theory is called Niratmavada or Not Self Theory [8]. Though he accepts the existence of soul, but claims soul to have different nature. According to Buddha, Soul is a bundle of Skandhas [5]. Skandhas are aggregates of heaps. Buddha claims the existence of 5 skandhas:
1) Matter
2) Impulse
3) Sensation
4) Perception
5) Consciousness

Buddha says that these Skandhas keep on changing, so soul also change. Change is reality. Today the world requires change. Buddha further explains rebirth by applying the logic of dependent origination and claims the death skandha to be linked with its previous birth skandha. Just like a candle lits a new candle similarly the previous skandha links the next skandha

Buddha has rightly said, "If with a pure mind a person speaks or acts, happiness follows them like a never-departing shadow" [2]. 


\section{CONCLUSION}

The basic concept of Buddhism is 4-noble truth where Buddha gives 8-fold path for attainment of highest bliss, Nirvana. The environment conservation by the application of 8 -fold path in human actions is the teaching of Lord Buddha. In the fast moving world today where people have felt tempted to embrace progress and modernization at the cost of the world itself has adversely affected the natural habitat and the moral principle of people. So, the question is can we apply Buddhas teaching for the preservation of nature and our moral principles?

\section{REFERENCE}

[1] World Religions by Number of Adherents- Buddha Net http://www.buddhanet.net/e-learning/history/bud statwrld.htm

[2] Real Buddha Quotes http://www.realbuddhaquotes.com/page/2/

[3] Bhikkhu Bodhi, "The Noble Eightfold Path" http://www.buddhanet.net/pdf file/noble8path6.pdf

[4] Professor Y. Karunadasa, "Pursuit Of Happiness: The Buddhist Way" 2013

Barbara O'Brien, "The Five Skandhas- An introduction to the aggregates", 2017.

[5] Mahatma Gandhi, quotes http://www.goodreads.com/quotes/427443-the-world-has-enough-for-ev eryone-s-need-but-not-enough

[6] Rick Hanson, "The First Noble Truth- The Noble Truth of Sufferings", 17 Nov

[7] Yung-Jong Shiah, "From Self to Non self: The Nonself Theory", Graduate Institute of Counseling Psychology and Rehabilitation Counseling, National Kaohsiung Normal University, Kaohsiung, Taiwan, 2016

[8] Cosmological Arguments, "Aquinas' Second Way" http://spot.colorado.edu/ heathwoo/Phil100/cosmo.html

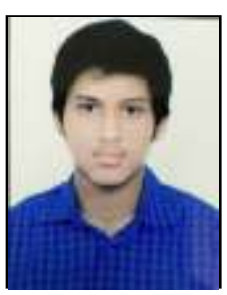

Snehansh Sinha was born on 4 April,1998. He did his high school from Amity International School, New Delhi scoring $95 \%$ in his class 12 . He is currently pursuing his Bachelor's from Delhi Technological University, New Delhi, India in Environmental Engineering field.

$\mathrm{He}$ is currently the president of a society "Cognitive Minds" in his college which aims at helping students to develop personality and prepare them for group discussions and personal interviews. He is also an active socialist and teaches underprivileged children of primary classes through a NGO, "Shades of Happiness" in New Delhi, India.

Mr. Sinha has won bronze medal at National Karate Championship, gold medal in Mathamity and $2^{\text {nd }}$ prize at Rock Climbing competition held at Manesar, India. He has done his internship at Advanced Level Telecom Training Centre (Asia's largest telecom training center) BSNL and worked on optical fibers. He has also interned as Business Research Developer at Earnt \& Young.

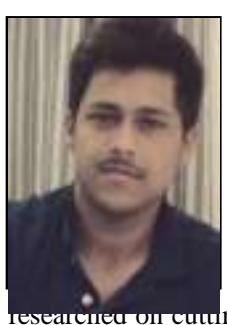

Swetank Sinha was born on 17 March 1995. He did his high school from Amity International School, New Delhi scoring $94 \%$ in his Class 12 . He has completed his Bachelor's in Technology in Environmental Engineering from Delhi Technological University this year in May 2017. In 2015, he was selected by Hitachi under their Concept for Renewable Energy Program through which he went for a full funded month long internship in Tokyo with the same company. He has ng edge technologies in the Petroleum sector during his time in Japan at Matsudo Research Center (Hitachi). He has also partnered with his brother Snehansh Sinha on their research on Optical fibers at Advanced Level Telecom Training Centre (Asia's largest telecom training center) in Ghaziabad, India.

Currently he is working as a Business Analyst for Successive Softwares, a NASSCOM listed software company. 